\title{
Tastafi Communication Strategy in the Development of Madani Community
}

\author{
T. Faizin ${ }^{1}$, Mohd. Hatta ${ }^{2}$, Abdullah ${ }^{2}$ \\ ${ }^{1}$ Ph.D Student in State Islamic University of North Sumatera (UINSU), Medan, Indonesia \\ ${ }^{2}$ Lecturer in in State Islamic University of North Sumatera (UINSU), Medan, Indonesia
}

\begin{abstract}
This research is titled Tastafi communication strategy in the development of Madani community. The focus of the problem in this study is, how to plan, and implement Tastafi communication strategies in the development of civil society. The approach uses in this study is a qualitative approach, with reasons to understand the problem in its natural setting, and interpret this phenomenon based on the meaning given by the informant, also because this research is multidimensional in nature resulting from the complexity of various situations, so the context surrounding it needs to be analyzed. The informants of this study are determined by purposive technique which was explored based on the purpose of this study, with 8 (eight) informants. Based on the data obtained, the results of this study are: first, Tastafi communication planning in the overall development of civil society through six stages, namely; (a) Identifying the vision and mission of Tastafi; (b) Seeing the condition of the people who need knowledge, especially monotheism, Sufism, Jurisprudence to help people from heresies, to do charity and morals; (c) Formulating objectives; (d) Determining sustainable programs and activities; (e) Designing pesandan material that will be delivered to the communicant to keep the message understood and interpreted according to the value of the substance of the implementation of ahlussunnah wal jama'ah; and (f) Selecting media in channeling their messages through recitations in mosques, prayer rooms, recitation centers, pulpits, mass media, print and online media. Second, Tastafi plays a role in several forms of implementation, namely the role of knowledge development through recitation, good discussion directly or through the media. Roles in the development of da'wah through taklim assemblies. Role in the development of community good deeds. The role of empowering Islamic scholars in a missionary organization. Role in leadership empowerment through activities for the sake of upholding Islamic law. Role in amar ma'ruf nahi munkar and role in developing ukhwah with dayah-dayah to cooperate in developing civil society through the Tastafi organization.
\end{abstract}

Keywords : strategy; communication; Tastafi; Madani community

\section{Introduction}

In Aceh, recitation activities have existed since the first time Islam arrived. When that was done at home, meunasah, dayah and mosque. Islamic scholars and announcer at that time had made recitation to spread Islamic propaganda in society through messages, so that the realization and upholding of Islamic law and the glory of Aceh. In the Acehnese language the message of enforcing the Shari'a in the Serambi Mekah earth is for example: adat bak Peutumereuhum, hukum bak Syiah Kuala, kanun bak Potroe Phang, reusam bak laksamana, adat ngon hokum, lagee zat ngon sifeut which means adat in the Peutumereuhum law in the syiah kuala, kanun in Putroe Phang, custom with laws such as substances and properties. ${ }^{1}$

\footnotetext{
${ }^{1}$ Pekan Kebudajaan Atjeh II, Prospek Sosial Budaya(Langsa: Panitia Pekan Kebudajaan Aceh, 1972), p. 45
} 
If we talk about the hope of the birth of glory, then surely the basic requirement is science. As Muslims, for us, the condition for the return of glory is to return to the path of Islam in totality (kaffah), so that the knowledge of monotheism, Sufism and Jurisprudence in society is the most basic prerequisite when we want to achieve glory. So this is where the movement to popularize science becomes a very essential need.

Therefore, the idea of the Chairperson of Ketua Himpunan Ulama Dayah Aceh (HUDA) Tgk. H. Hasanoel Basry (Abu MUDI) who gave birth to the Tastafi Council (Sufism, Tawheed, and Fiqh) which is now increasingly rooted in Acehnese society is something that should be appreciated as high as possible. It is not easy to make people interested in science, especially Sufism, Tawheed and Jurisprudence which cover all the problems of Islam and Muslims, covering the world and the hereafter at the same time. In various places every time the Tastafi recitation is held and cared for by the scholars, the enthusiasm of the community welcomes it. Communities flock to every corner of the field and the room where the recitation is held. Aside from Tastafi, there are actually other similar recitals such as Sirul Mubtadin, Majelis Taklim Asy-Syifa and others who have strong magnets attracting large numbers of worshipers. However, these recitations have similarities with Tastafi in the content of the material and the characters.

So in delivering an Islamic message through an organization, Tastafi study council requires a persuasive and effective communication. In the perspective of Islam, that communication is very important role for human life in socializing, humans are required to be clever in communicating. This is explained in the Qur'an the letter Ar-Rahmaan verses 1-4,

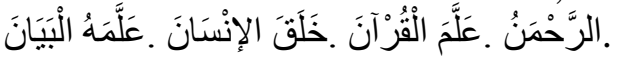

Meaning: "(God) the most generous, who has taught the Koran. He created humans, his teaching was good at speaking"2

The occurrence of communication is a consequence of the existence of social relations. Society consists of at least two people who are interconnected with one another who, due to their relationship, give rise to social interaction. In this social interaction there is communication with one another, which is called intercommunication. ${ }^{3}$

An effective communication must go through a good planning or formulation, taking into account several elements, which are even easier when referring to Laswell's view, which tries to simplify the communication by answering Who Says What Are the Channels to Whom With Effect ?, namely by pay attention to all components or elements contained in communication such as communicators as messengers, what is conveyed, with what media is delivered, to whom it is delivered and what effects are expected, then it is expected that the message conveyed and carried out.

Tastafi is required to have a good communication strategy, by determining who, what, with whom and to whom the message must be delivered. Because the success of a communication is determined by the strategy used by a communicator in communicating his message. In other words, a communication that does not pay attention to a good strategy will experience failure which ultimately does not arrive at the intended purpose. Anwar Arifin states that in fact a strategy is the whole conditional decision about the action to be taken, in order to achieve the goal. So formulating a communication strategy, means taking into

\footnotetext{
${ }^{2}$ Departemen Agama Republik Indonesia, Alquran dan Terjemahnya,(Bandung: Diponegoro, 2008), p. 775.

${ }^{3}$ Onong Uchjana Effendy, Dinamika Komunikasi (Bandung: Remaja Rosdakarya, 2002), p. 3.

DOI : https://doi.org/10.33258/birci.v2i2.260 
account the conditions and situations faced and that might be faced in the future, in order to achieve communication goals.

Thus, this communication strategy, means that it can be taken several ways to formulate a strategy by considering the material, location, methods and media that will be carried out in the communication. In another definition it is also stated that communication strategies are planning and management. Therefore, a communication strategy must be operationally translated so that it can be clearly practiced. Of course, this requires an approach that can vary according to the situation and conditions.

\section{Review of Literature}

\subsection{Communication Strategy}

The word strategy comes from Greek strategos and refers to the overall role of command such as a military command. In business, strategies determine the scope and direction of an organization's development and how to achieve a competitive strategy. ${ }^{4}$ According to Glueck, Strategy is a unified, comprehensive and integrated plan that connects the strength of the company's strategy to the environment faced in order to ensure the achievement of key goals and objectives.

According to Onong Uchjana the communication strategy is essentially a guide to planning commucation and management communication to achieve the goal. But to achieve this goal, the strategy does not function as a road map that only shows direction, but must show how its operational tactics.

Departing from the general understanding of strategy and communication strategies, it provides an understanding that this communication strategy is a variety of methods and methods carried out for smooth communication to achieve the goals described in the organization's vision and mission. The communication strategy also becomes the foundation and preparation steps for how to avoid and deal with problems that arise later.

The success of many effective communication activities is determined by determining communication strategies. On the other hand, if there is no good communication strategy, the effect of the communication process (especially mass media communication) is not impossible to cause negative influences. Whereas to assess the communication process can be explored using communication models. In the process of ongoing communication activities or the completion of the process, to assess the success of the communication process, especially the effects of the communication process, the study of the communication model is used.

The communication strategy also has several quality criteria or standards. The communication strategy starts with:

a. Identify vision and mission. Vision is the long-term ideal that can be achieved by communication. Vision formulation usually consists of "a few words" that contain goals, expectations, ideal ideals of communication. From the formulation of the vision, a mission will be formulated which describes these ideal ideals.

b. Determine programs and activities. Programs and activities are a series of activities that must be done, programs and activities are a translation of the mission.

\footnotetext{
${ }^{4}$ Keith Butterick, Pengantar Public Relations, (Jakarta: Raja Grafindo Persada, 2011), p. 153. DOI : https://doi.org/10.33258/birci.v2i2.260 
c. Determine goals and results. Every program or activity usually has a goal and results to be obtained. Usually the policy makers make definitions of the objectives and results to be achieved.

d. Selection of the target audience. Communication planning determines the category of the audience that is the target of communication.

e. Develop messages. The criteria are all messages that are designed as far as possible to have specific, clear, persuasive content, and reflect audience values, the appearance of content that can provide solutions for the community, or show certain actions.

f. Identification of the messenger. Communicator criteria include credibility, credibility in science, expertise, and skills related to certain issues.

g. Communication / media mechanism. The criterion is to choose media that can facilitate the mechanism of sending and sending back or exchanging information. The criterion of the media is the media that is easily accessible or the most preferred by the audience.

h. Scan for context and competition. The criterion is to calculate risks and contexts that will influence communication strategies, for example calculating opportunities to win the competition by winning the hearts of the audience.

The criteria of this strategy are very much needed in the organizational communication planning procedures, what are the results of the workmanship of these criteria determines the communication of how and with what will be carried out in the organization. Furthermore, organizational leaders will be able to make a basic reference in making decisions and solving problems both within the organization and within the organization.

\subsection{Communication Planning}

Communication planning is very necessary and needed before we carry out activities and take to the field to make an observation. Based on Hafid Cangara, communication carried out does not escape from various obstacles or obstacles. The communication planning process is intended to overcome the obstacles that exist in order to achieve the effectiveness of communication, while in terms of function and usefulness of planning communication is needed to implement the programs to be achieved, whether for imaging or marketing. There is no communication planning model that can be used universally (no ideal), but in accordance with the conditions and reality that exists.

Communication planning is very necessary to develop communication strategies so that the desired program can succeed. Without planning, implementing an activity will experience difficulties and even failure in achieving the desired goals. As a first step for all types of activities, planning also initiates all stages of development so that development goals can be achieved with available resources and sources of funds. According to Dilla, communication planning is the basic thing needed in a social communication activity, mainly to introduce or market products. After understanding the planning process and the elements of communication within an organization, several things can be found that are problems in planning communication.

There are several substances from the above understanding of communication planning, namely communication planning as a deliberate, written effort, the application of knowledge and the art of communication, arranged systematically and continuously, the goals to be 
achieved within a certain period of time, the determination of resource allocation, using the basic elements of communication, and the existence of measurement and evaluation.

The opinions above also imply that planning is a process that contains activities in the form of thoughts, calculations, elections, determinations and so on, all of which are carried out in order to achieve certain goals. In essence, planning is a decision-making process for a number of alternatives (choices) regarding the goals and ways that will be implemented in the future in order to achieve the desired goals and monitoring and evaluation of the results of their implementation carried out systematically and sustainably.

\section{3. Madani Commnity}

Civil society is formed from a combination of the words "community" and "madani." Both of these words, together are absorption words from Arabic that have been standardized into Indonesian vocabulary. Therefore, in order to easily understand this concept, it will be explained the second meaning of the word.

KBBI defines the word community with meaning, "a number of people in the broadest sense and are bound by a culture that they consider the same.

The word community itself, comes from Arabic, namely the root word consists of letters sh (ش), ra (ر), and kaf (ك)). From the root words are formed such as, shirk, sharīkat, and shirkah-sharikah. The first word, according to al-Munawwir's Dictionary, means fellowship. The second word means the union, association, association, group. ${ }^{5}$ While the third word according to the Dictionary of al-Maurid, means company, corporation, firm, business, partnership, and association. In al-Munjid's dictionary it is said that al- sharikat is "الاختلاط" which means mixed up.

In terms of terminology, according to M. Quraish Shihab's search for the verses of the Qur'an, it is concluded that society is a collection of many small individuals or large individuals who are bound by units, customs, rites or laws, and live together. In the Qur'an there are several words which is used to refer to people or groups of people. Among other things: qawm, ummah, sha'b, and qabilah. Ali Nurdin added eight terms of society besides that, such as firqah, täifah, hizb, fauj, expressions beginning with ahl, expressions beginning with $\bar{a} l u$, al-nās, and asbāt. These terms, by the Koran, are characterized by certain attributes, such as al-mala ', al-mustakbirūn, al-mustadh'afün, al-muslimūn, al-mu'minūn, al-mushrikūn, ahlal-Kitāb, and others. Quraysh Shihab and Dawam Rahardjo concluded from the many terms of society used in the Qur'an, said the ummah who had been Indonesianized as a people, closer to the understanding of the community.

The madani word, rooted in the word masdar (noun) of the sequence dal (د), ya (د) dannun (ن) of fi'ilmadi (verb) dāna (دان) The word derivates in the form of the word dain (taking debt) and din (religious, submissive, and submissive).

Harun Nasution and Nurcholish Madjid agreed that the term din was in line with religion, law or law. In Arabic, the word also means mastering, submission, obedience, debt, retribution and habits. The Dina are the bonds that humans must hold and obey. Between the two meanings of polaini (debt and religion) there is a close relationship. Debt is something that must be paid, and religion is essentially the responsibility that must be fulfilled by humanity in the form of service to the Creator. In addition, the derivation of the word also

\footnotetext{
${ }^{5}$ Ahmad Warson al-Munawwir, Kamus al-Munawwir, (Surabaya: Pustaka Progressif, 1997), p. 715. See also Mahmud Yunus, Kamus Arab Indonesia, (Jakarta: Hidakarya Agung, 1992), p. 196. 
becomes the word Madinah as ismmakān which is a change from the word Madyan which in the Qur'an is referred to as the city where Syu'aib lives. From the word madyan and madinah through phoneme adjustment the madani word is formed as the ratio of the word madinah, which is the ideal city built by the Prophet. Thus, it can be said essentially that civil life is characterized by the rule of law in the life and order of society.

Madinah in terms of etymology, comes from the same root word as madaniyah, which means civilization. Literally, the word madinah is a place of civilization or a civilized environment, which is characterized by civility and not wild. In Arabic, the equivalent of the madaniyah term is hadārah (حضارة) the notion of origin is sedentary living patterns. This understanding is very closely related to the term thaqâfah (نقافة), a equivalent in Arabic for culture.

\subsection{Tastafi Profile}

The Assembly of Recitation and Recitation of Sufism, Tawheed, and Jurisprudence is abbreviated as Tastafi, an assembly that examines the science of Jurisprudence, Tawheed, and Sufism. The birth of Tastafi was spearheaded by Tgk. H. Hasanoel Bashri, better known as Abu MUDI on Thursday 7 June 2012 M, coinciding with the 17th of Muharram $1433 \mathrm{H}$. The Assembly of Tastafi is centered and has a legal position in Samalanga, Bireuen Regency, Aceh Province. Tastafi recitation activity was originally located in the Baiturrahman Banda Aceh Grand Mosque led by Abu MUDI Samalanga on March 7, 2014. Tastafi was officially incorporated on December 29, 2017. The establishment of the Tastafi Organization was at the initiative of Dayah scholars, intellectuals and educators. -dayah both in Aceh, national and international, they agreed to deliver and ground the teachings of Sufism, Tawheed, and Jurisprudence based on the Qur'an, Sunnah, Al-Ijma ', and Al-Qiyas, as well as the meaning of Ahlussunnah waljaamaah, and principles the principle of the Unitary Republic of Indonesia based on Pancasila and the 1945 Constitution of the Republic of Indonesia.

Tastafi is a community organization that is engaged in studying, developing and broadcasting Islamic Studies that adheres to Ahlusunnah wal jama'ah in the fields of Tawheed, Jurisprudence and Sufism. The word Tastafi as an abbreviation of Sufism, Tawheed and Jurisprudence does not indicate the sequence of the positions of the scientific fields but an abbreviation to facilitate the mention. While the sequence of scientific positions still refers as regulated by the ulama in the books of muktabarah.

The existence of the Tastafi organization is to strengthen ukhuwah Islamiah and harmonization between religious groups, recitation centers, majelis taklim and communities in religious, national and state life, as a form of social concern in developing devotion to Allah SWT for the realization of civil society.

Tastafi in daily life based on the Qur'an, hadith, ijma', and qias, is manifested in various forms of livelihood activities and establish ukhuwah and friendship in fostering and developing Islamic culture, getting to know each other, helping, and worshiping in the right way, in order to strengthen and realize the pattern of Islamic community life. Tastafi is also a reflection of Indonesianness by maintaining national unity and unity in various activities while taking into account the diversity that is possessed. Tastafi not only takes care of and focuses on amaliah and taklim (beut seumeubeut) but also engages in other scientific fields, both culture, technology (science and technology), social, economic, legal, and institutional and management arrangements and others with maqasidul ammah to produce studies, innovations, contributions of thoughts and real works in the life of the nation and state. 
Tastafi seeks to prevent the birth of misguided notions and deviations from manhaj's knowledge and faith Ahlisunnah wal jama'ah (Aswaja) as brought by the Messenger of Allah. Today the younger generation and society prefer to follow something new inherited by nonMuslim thought and the like both secularism, pluralism and liberalism.

The development of has now progressed very rapidly, this indicates that the existence of Tastafi is highly expected by the community and welcomed by the community. Until now, pengajian and Tastafi assemblies have begun to develop in various remote areas throughout Aceh and outside Aceh.

\subsection{Implementation of the Tastafi Communication Strategy}

Regarding the role of Tastafi in the development of civil society as a communication implementation strategy that has been designed by the organization the researcher takes a sample of research through a purposive sampling technique by selecting several Tastafi administrators as key persons who are credible Ulama figures in their fields. The researcher conducted an interview with the informant and conducted field observations.

The first informant was Tgk. H. Hasanoel Bashry HG as the founder of Tastafi. According to him the strategy carried out for civil society development through Tastafi, namely:

The role of Tastafi in building civil society, among others: introducing the public about Islam with the knowledge in particular the science of tawhid tasawuf and figh then practicing it; motivating Islamic practice in life; do activities based on Islam; every policy and attitude must not be separated from Islamic values that understand ahlussunnah wal jamaah; see every problem that occurs in the community and resolve the problem. Then the empowerment of knowledge is certainly by the pious people who master their fields. Dayah that I lead now has given birth to many alumni where their work in their respective regions has been acknowledged by the community through assemblies and dayah. So I direct my initiative and empower them systematically through Tastafi" 6

Tastafi role in developing civil society is inseparable from the name of its founder, Tgk. H. Hasanoel Basri HG, better known as Abu MUDI. Kharisma Abu MUDI as a Ulama who is very well known by the people of Aceh who always do direct service in the community through Tastafi recitation. In addition to Abu MUDI, in the Tastafi organization, the Acehnese charismatic ulama joined the majority of the leaders of Dayah so that branding Tastafi through their figure was very strong in the community. In this case Tastafi has made efforts to empower ulama as administrators in the organization.

Introducing society about Islam must be with knowledge. The purpose of introducing society to science is that the community must be educated by studying religion and practicing the knowledge. Because of the current phenomenon, all levels of society need religious education. Then we are obliged to teach the knowledge of religion to the community. Community development through education according to Tgk. H. Hasanoel Basri HG, in addition to making his dayah as one of the media publications, is in the majelis taklim in the community. Dayah is one of the very good media, but the knowledge delivered is only limited to the santri in the dayah. The effort to level education to all was done so that the

\footnotetext{
${ }^{6}$ Interview with founder TASTAFI Tgk. H. Hasanoel Bashry HG, 15 October 2018 in Samalanga districts Bireuen. 
general public could also attend education, an idea emerged from Tgk. H. Hasanoel Basri HG, need to teach the taklim assemblies that have been formed by each region within the respective Regency area by the dayah alumni.

Tastafi recitation is in the form of teaching and learning and question and answer sessions conducted for adult worshipers, both ladies and gentlemen. This recitation is usually done once a week or twice a week with a predetermined time schedule while the place of recitation is sometimes a mosque, musalla, or meunasah. While the recitation material is usually adapted to the needs of the participants, it revolves around tauhid, tasawuf and fiqh, aqidah and socio-religious and social problems. This form of recitation is carried out in the working area of each Tastafi branch both in the city and in the Village, in every Mosque and Musalla and in each study hall even in almost every meunasah. While the teacher who provided the material was a scholar and dayah alumni who had been credited with credibility. Recitation like this is multilevel, there is the lowest recitation, the discussion is still about thaharah, the practice of prayer, in matters of jurisprudence and the nature of 20 in the field of monotheism and the same level. There are also those who are already in the middle level, have discussed the problems that are being faced and needed that are in accordance with Islamic teachings. And in certain cases there are those who are already high level, whose participants are teungku who already have a high level of religious knowledge. They are digging the books whose discussion is already high. ${ }^{7}$

Regarding the activities of Tgk. H. Hasanoel Basri HG to the Tastafi Assembly, he is active in recitation which exists throughout Aceh, Indonesia and even abroad, including: Banda Aceh, Sigli, Bereunuen, Samalanga, Bireuen, Takengon, Idi, Bambong, Blang Pulo, Matang Glumpang two , Kembang Tanjong, Meru Malaysia, Kajang Malaysia, Medan and Jakarta.

Abu MUDI gave a special recitation of senior santri who were administrators and members of Tastafi in Balee Beuton every day after dawn until 7:15 a.m. by studying the books of fiqh namely Tufatul Al-Muhtaj by a great scholar Ibn Hajar Al-Haitamy on Saturday to Tuesday and the Ihya-Ulumuddin book by Imam Al-Ghazali on Wednesday to Thursday.

\section{Discussion}

The success of effective organizational communication activities is largely determined by the determination of communication strategies. On the other hand if there is no good communication strategy the effect of the communication process will certainly have a positive effect. Communication strategy is the first step in every program that wants to be run by an organization, the existence of a communication strategy will form intuition for each member that the program will be carried out as much as possible without any obstacles and the speed of the process of achieving goals. The emergence of this communication strategy is certainly motivated by the estimation of constraints that will appear when the program is run. Another viewpoint of communication strategies is needed so that organizational goals can be achieved by using various needs effectively and efficiently.

Seeing Tastafi by implementing so many programs of course without a good communication strategy, the program will experience stagnation and even failure to be achieved. Every idealistic program will not be separated from structured planning, carried out

\footnotetext{
${ }^{7}$ Observation of researchers on several Tastafi recitations 
with good management and achieved goals as the effect of the final results of the program. Every aspect of this program, namely planning, application, and implication, of course, is governed by the flow of communication strategies.

Before establishing a program that will be implemented, Tastafi first conducts research on the capabilities, feasibility, needs of Tastafi and the community and the impact of the program. The discovery in each of these stages will be a consideration for the chairman, especially in legalizing or not the program to run. The three stages before the establishment of the program can be said as a communication strategy in general or pre communication strategies in each program.

By defining a communication strategy as a guide to communication planning and communication management to achieve goals as stated by Onong Uchjana, Tastafi adheres to a system that in planning a program must have 6 (six) stages namely; (a) Identifying the vision and mission; (b) Seeing the condition of the community; (c) Formulating objectives; (d) Determining programs and activities; (e) Designing messages; and (f) Selecting Media and evaluation. These six types of stages are implemented by Tastafi in each of its roles. The five stages applied by Tastafi in this plan are in accordance with Dilla's opinion, and so do not deviate from Cutlip and the Center in the communication planning theory that it triggered.

Dilla said that to do something the activities carried out would be able to achieve results as expected to use the plan. In the field of communication, communication planning is known. Communication planning has several stages, namely; audience analysis, goal setting, media selection, message design, and program evaluation.

Also, if you look at what Tastafi has done in planning communication, it has fulfilled the stages offered by Cutlip and the Center. they offer four steps commonly used in communication planning, namely; (a) Fact Finding or fact finding, conducted to find out the situation of the community whether supporting or inhibiting activities. (b) Planning, carried out by gathering information, analyzing information, identifying problems, looking for underlying causes, identifying alternatives, calculating strengths, adjusting plans, monitoring activities and selecting monitoring methods. (c) Communication, is a continuous process to connect goals with the internal environment, as well as external (external public). This stage is inseparable from the planning of how to communicate and what is communicated. (d) Evaluation, aims to find out the impact or influence on the public or audience by answering the question whether the output is in accordance with the objectives, how to be better in the future, and whether the results are in accordance with the plan.

The pattern in the process is described as follows:

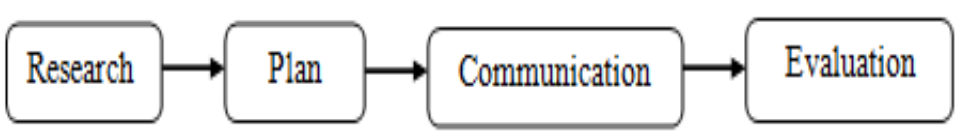

Comparative results between Dilla's opinion, Cutlip's theory and the Center with the implementation of Tastafi related to communication planning have been fulfilled and are in line between theory and implementation. But just naming different terms, for example Dilla named the analysis of audiences, Cutlip and the Center named the discovery of facts, and TASTAFI itself named the condition of society. Different names on each of these parties do not have a substantial value from the first stage in this communication plan.

The existence of a communication strategy that is applied in planning to realize each role carried out by Tastafi accumulatively has been able to answer the problem of society in DOI : https://doi.org/10.33258/birci.v2i2.260 
its development towards a civil society. In the Tastafi study, for example, with the presence of scholars who have credibility and experts in the field of Islamic religion, people can ask questions about the law that is not yet known the answer or the law that is having problems among them. The resource person answers set by Tastafi have been able to answer the problems raised and provide alternative solutions to the problems that are being phenomenal in the community. Besides that, it became a solution in the development of more organized da'wah with the presence of da'i Tastafi.

In Aceh and also in other Muslim countries, ulama have always been a more respected community group. Indeed there are periods of decline and increase, but that is only because it is influenced by certain situations and circumstances. For example, the ulama sometimes functions as a teacher and advisor but also a decision maker and executor of the decision. When its position as executor of the decision, the ulama will look more authoritative, because the ulama can carry out according to what he said. If the ulama sees something immoral, he himself will eradicate it because the authority is in his own hands.

One of the ulama's tasks was to convey the message of $d a^{\prime}$ wah to the entire community, because the ulama were "waratsatul ambiyā" connecting messages from the Prophet Muhammad. In carrying out da'wah activities, of course there are differences in the delivery of one dayah cleric and other Islamic scholars, because it depends on the quality of the knowledge, the background of the knowledge they have, and the methods used to convey their da'wah.

Educational background is one indicator to determine the competencies possessed by a dai. Competition here means a set of intelligent actions full of responsibility that must be possessed by someone as a condition to be considered capable of carrying out tasks in the field of da'wah.

In the prospect of source credibility in communication science that education can be used as a benchmark for preachers in assessing their professionalism as preachers who convey messages of communication, as explained by Hovland, Janis, and Kelley in 1953 as figures who developed the theory This communication explains that it is possible for someone to be persuaded (persuaded) if the sources of persuasion (can the communicator itself) have sufficient credibility.

According to the habits that occur in the community that individuals are more trusted and tend to be well received messages conveyed by people who are experts in their fields, this can be illustrated in the situation of pilgrims who tend to see the title of the ulama carried by dai, if supported by the delivery of da'wah interesting. As in the research findings that conveying the message through Tastafi recitation in several regions was Acehnese scholars who had been recognized by their community's credibility.

Thus, the management and members of Tastafi who have a dayah background education show that judging from their educational background and experience, all of them have adequate qualifications for carrying out da'wah duties and have prerequisites as dai, if viewed according to the source credibilty in terms of their knowledge. in the field of Islamic science.

The discovery of the concepts formulated by Tastafi in developing civil society according to the author has been good, except that Tastafi needs to utilize more optimal mass media to inform about the science of monotheism, Sufism and Jurisprudence, with widespread information about the concept of vision or mission built by Tastafi and also will be able to realize the ideals of civil society. 
In accordance with the above, if it is connected with diffusion of innovation, a concept of knowledge transformation, empowerment of ulama, umara, interwoven ukhuwah and media that are widely disseminated through mass media, online and electronically will be able to give influence to people to actualize organizational goals.

The diffusion of innovation is that communicators who get messages from the mass media are very strong to influence people. Thus, the existence of innovation (discovery), then disseminated (diffusion) through the mass media will greatly influence the masses to follow it.

Initially the above theory, departing from the communication of two-step flow models slowly developed into a multi-step flow model that is often used in diffusion research, namely the writing of social processes on how social innovations (ideas, practices, new objects) become known and spread throughout the social system. The flow of the first two steps deals with how individuals receive information and pass it on to others, while the diffusion process concentrates on the final step of adoption or rejection of innovation.

If it is concluded, according to this theory something new will cause people's curiosity to find out. Someone who finds new things tends to socialize and disseminate to others. So it's perfect, the inventor wants to spread, while other people want to know it. Then, mass media was used to introduce the new discovery. So between inventors, users, and the mass media both benefit.

The results of the dissemination of information about innovations carried out by scientists will be adopted by the community, as a positive reaction to innovation in terms of its utilization. Associated with the adoption process, William McEwen as quoted by Josep A. Devito (1997) identified the following three stages: (a) In the information acquisition phase, people obtain and understand information about innovation. For example, a lecturer learned about a new design to give lectures in a large number of classes; (b) In the information evaluation phase, people evaluate information. For example, the lecturer realized that the new method was more effective than the old method; and (c) At the stage of adoption or rejection of people adopting (implementing) or rejecting innovation. For example, the government made a motto as a method developed in the vision and mission of development.

So it can be concluded that through the theory of innovation-diffusion is suitable in providing stimulus for the communicant, in terms of providing information and also new thinking to make changes in the society, because the nature of each individual is happy with new things. Therefore, according to the author that what Tastafi designed with what it wants to be socialized through its activities in building the civilization of Acehnese society in particular and generally dignified Islamic societies is so good, even though this organization is still new, it is only the preparation of steps and the integration of vision and mission which is understood between the management, members and government support must be in line and collaborate, so that there is no misunderstanding (misunderstanding) in achieving the final goal to be desired.

\section{Conclusion}

Tastafi communication planning in developing civil society as a whole through 6 (six) stages namely; (a) Identifying the vision and mission of Tastafi; (b) Seeing the condition of the people who need knowledge, especially monotheism, Sufism, Jurisprudence to help people from heresies, to do charity and morals; (c) Formulating objectives; (d) Determining 
sustainable programs and activities such as formulating the current law through lajnah, holding tawheed recitation, Sufism and fiqh, fostering $u k h w a h$, dayah utilization as a base of Tastafi; (e) Designing pesandan material that will be delivered to the communicant to keep the message understood and interpreted according to the value of the substance of the implementation of ahlussunnah wal jama'ah; and (f) Selecting media in channeling their messages through recitation in mosques, prayer rooms, recitation centers, pulpits, mass media, print and online media.

Tastafi plays a role in several forms of implementation, namely the first, the role in science development through recitation, discussion both directly and through the media. Second, the role in the development of da'wah through taklim assemblies. Third, the role in fostering good deeds of the people. Fourth, the role of empowering Islamic scholars in a missionary organization. Fifth, the role in leadership empowerment through activities for the sake of upholding Islamic law. Sixth is the role in amar ma 'ruf nahi munkar and the seven roles of fostering ukhwah with dayah-dayah to cooperate in developing civil society through the Tastafi organization

\section{References}

Abdullah bin Muhammad, Tafsir Ibnu Kasir, Juz-IV, Bandung: Sinar Baru Algensindo, 2003. Ahmad Warson al-Munawwir, Kamus al-Munawwir,Surabaya: Pustaka Progressif, 1997.

AliNurdin,Qur'anicSociety:MenelusuriKonsepMasyarakatIdealdalamAlqur'anJakarta:Erlan gga, 2006.

Alo Liliweri, Komunikasi Serba Ada Serba Makna, Jakarta: Kencana, 2011.

Al-Sayyid Ahmad al-Hashimī, Jawāhir al-Balāgah fì al-Ma'ānī wa al-Bayān wa al-Badī'̄̄, Mesir: Dāral-Fikr,1991.

Anwar Arifin, Strategi Komunikasi, Jakarta: Rineka Cipta, 1984.

Anwar Kuta Krueng, Dayah dan Rabithah Thaliban dalam Catatan Aceh, Banda Aceh: Rabithah Thaliban Aceh, 2010.

Departemen Agama Republik Indonesia, Alquran dan Terjemahnya,Bandung: Diponegoro, 2008.

Departemen Pendidikan Nasional, Kamus Besar Bahasa Indonesia Jakarta: Balai Pustaka, 2007.

Dilla Sumadi, Komunikasi Pembangunan Pendekatan Terpadu, Bandung: Simbiosa Rekatama Media, 2007.

F. Rachmad, Public Relations dalam Teori dan Praktek, Jakarta:. Gramedia Pustaka Utama, 1993.

Hafi Anshari, Pemahaman dan Pengalaman Dakwah: Pedoman Untuk Mujahid DakwahSurabaya: Al-Ikhlas, 1993.

Hafied Canggara, Perencanaan dan Strategi Komunikasi, Ed. I, Cet. I, Jakarta: Rajawali Pers, 2013.

Hasbi Amiruddin, Menatap Masa Depan Dayah di Aceh, Yogyakarta: Polydoor, 2009.

Jalaludin Abdurahman Ibn Abi Bakr Al-Suyuti, Al-Jami' al-Shagir fi Ahadits al-Basyir alNadzir, Juz II, Beirut: Dar al-Fikr, t.th.

John Farlong dan Frisha Maynard, Monitoring Student Teachers London: Ruutledge, t.th.. Keith Butterick, Pengantar Public Relations, Jakarta: Raja Grafindo Persada, 2011. 
Luwis Ma'lūf, al-Munjid fì al-Lugah wa al-'A'lām, Bairūt: Dār al- Mashriq, 1977.

M. Quraish Shihab, Wawasan al-Qur'an: Tafsir Mandhu'i atas Pelbagai Persoalan Umat, Bandung: Mizan, 1998.

Matondang,Kepemimpinan Budaya Organisasi dan Manajemen Strategi, Yogyakarta: Graha Ilmu, 2008.

Muhammad Nashiruddin Al-Bani, Ringkasan Shahih Bukhari, Juz-IV, Penerbit: Pustaka AsSunnah, 2005.

Nurudin, Pengantar Komunikasi Massa, Ed. I Cet. II; Jakarta: PT. Raja Grafindo Persada, 2007.

Onong Uchjana Effendi, Ilmu Komunikasi Teori dan Praktek, Bandung: Remaja Rosdakarya, First Edition, 1999.

Onong Uchjana Effendy, Dinamika Komunikasi, Bandung: Remaja Rosdakarya, 2002.

Pawit M. Yusup, Ilmu Informasi, Komunikasi, dan Kepustakaan, Ed. I, Cet. I; Jakarta: Bumi Aksara, 2009.

Pekan Kebudajaan Atjeh II, Prospek Sosial Budaya, Langsa: Panitia Pekan Kebudajaan Aceh, 1972.

Rūhī al-Ba'albak̄î, al-Maurid Qāmūs 'Arabì-inkalījī, Modern Arabic-English Dictionary, Bairūt: Dār al-'Ilm lī al-Malayīn, 1995.

S.J.Taylor dan R.Bogdan, Introduction to Qualitative Research Methods, New York: Willey, 1984.

Sharan. B. Merriam, Case Study Research in Education: A Qualitatif Approach,San Fransisco: Jossy-Bass Publishers, 1988.

Sugiyono, Metode Penelitian Kualitatif, Bandung: Alfabeta, 2005.

Syaikh Salim bin 'Ied Al-Hilali, Syarah Riyadhush Shalihin, Jakarta: Pustaka Imam Syafi'i, 2005.

Taufik Abdullah (et. All), Agama dan Perubahan Sosial, cet. 1, Jakarta: Raja Grafindo Persada, 1996.

Werner J. Severin dan James W. Tankard, Jr., Teori Komunikasi: Sejarah, Metode, dan Terapan di Dalam Media Massa, Ed. 5, Cet. 4; Jakarta: Kencana, 2009. 